\title{
Parents' Perspective of the Young Marines as a Youth Leadership Program
}

Rebecca Van Deusen

Cedarville University

Follow this and additional works at: http://digitalcommons.cedarville.edu/education_theses

Part of the Civic and Community Engagement Commons, Community-Based Learning Commons, Education Commons, and the Service Learning Commons

\section{Recommended Citation}

Van Deusen, Rebecca, "Parents' Perspective of the Young Marines as a Youth Leadership Program" (2011). Master of Education Research Theses. 49.

http://digitalcommons.cedarville.edu/education_theses/49 
Parents' Perspective on the Young Marines

Running head: PARENTS’ PERSPECTIVE ON THE YOUNG MARINES

\title{
PARENTS’ PERSPECTIVE OF THE YOUNG MARINES \\ AS A YOUTH LEADERSHIP PROGRAM
}

\author{
A thesis submitted in partial fulfillment \\ of the requirements for the degree of \\ Masters of Education
}

By

\section{REBECCA SUE VAN DEUSEN}

B.S. Education, Cedarville University, 1995

2011

Cedarville University 
SCHOOL OF GRADUATE STUDIES

July 20, 2011

I HEREBY RECOMMEND THAT THE THESIS PREPARED UNDER MY SUPERVISION BY Rebecca S. Van Deusen ENTITLED Parents' Perspective of the Young Marines as a Youth Leadership Program BE ACCEPTED IN PARTIAL FULFILLMENT OF THE REQUIREMENTS FOR THE DEGREE OF Master of Education.

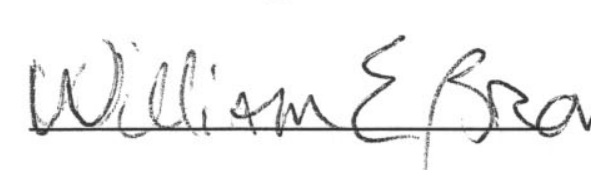

William E. Brown, Ph.D.

President

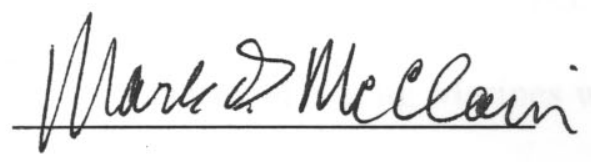

Mark McClain, Ph.D.

Associate Academic Vice President

College of Professionals

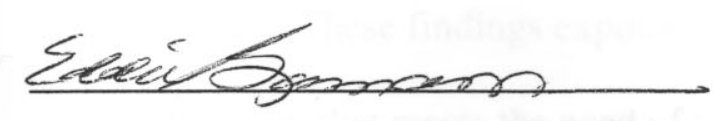

Eddie Baumann, Ph.D.

Thesis/Project Advisor

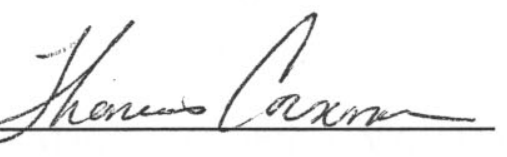

Thomas Cornman, Ph. D

Academic Vice President

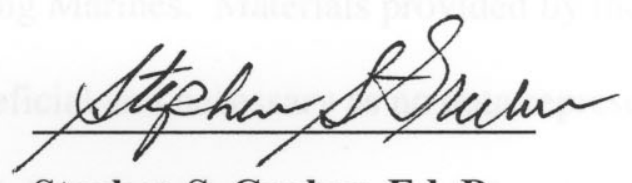

Stephen S. Gruber, Ed. D.

Education Department Chair

Director of M.Ed. Program

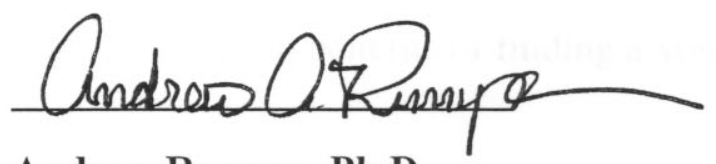

Andrew Runyan, Ph.D.

Graduate School Dean 


\begin{abstract}
Van Deusen, Rebecca S. M.Ed., Education Department, Cedarville University, 2011. Parents' Perspective of the Young Marines as a Youth Leadership Program.
\end{abstract}

Despite the number of youth development programs, little is clear about the essence and structure of the Young Marines through the eyes of the parents. Drawing on both the literature and the data gathered through in-depth interviews from parents, this study aims to examine parents' views, their understanding and perspective. Data collected for this study comes from one primary source: Young Marines, Quantico, VA. Through a phenomenological study, the researcher's participants give insight, knowledge, and descriptive life experiences about the Young Marines. Materials provided by the National Young Marines website was beneficial and necessary as no data represents the Young Marines in the literature researched. Research shows that youth development programs are effective and necessary. While this study has proved to be beneficial, additional studies are necessary to compare results with other units throughout the United States. These findings expound on the challenges, limits, and benefits of finding a youth program that meets the need of youth.

Keywords

Parents’ perspective of youth programs, youth leadership programs, youth programs, promoting healthy adolescents, promoting youth adolescents, positive youth development 
Parents' Perspective on the Young Marines

\section{TABLE OF CONTENTS}

1. Introduction to the study
a. Social institutions (family, religious organizations, school, youth leadership)
b. Definitions of terms
c. Statement of problem
d. Scope of the study and delimitations
e. Significance of the study
f. Methods of procedure

2. Plenary literature review
a. Youth character \& development
b. Successful youth programs
c. The Young Marines Organization

3. Methodology
a. Population and sample
b. Procedure

4. Results \& Analysis
a. Decision to join, role in decision
b. Parents' perspective of the program
c. The impact it has had on their youth
d. Why parents and youth are giving back to the community
e. Views on youth leading the youth 
Parents' Perspective on the Young Marines

5. Discussions \& Implications
a. Interpretations of the results
b. Potential applications of findings
c. Biblical integration \& implications
d. Strengths of Study
e. Limitations of the study
f. Suggestions for future research 
Parents' Perspective on the Young Marines

\section{LIST OF TABLES}

Table

Page

1. Number of divisions and states being served

through the Young Marines.......................................28

2. Demographics of Young Marines located in Quantico, VA.............32

3. Demographics of Young Marines located throughout the USA.........32 


\section{Chapter One: Introduction to the Study}

\section{Parents' Perspective of the Young Marines as a Youth Leadership Program}

Youth are an important part of our society. The need and desire for them to participate in activities apart from school is crucial for our communities. According to the Corporation for National \& Community Service [(CNCS),2005], volunteering plays valuable role in shaping how youth learn to interact with their community and develop skills, values, and a sense of empowerment necessary to become active citizens. Social institutions, including schools and churches, play an important role in helping shape our youth. Many believe, as Louis Harris and Associates (1998) suggest that the activities in which youth interact with will have a positive effect on them that will remain throughout their lifetime. As stated by former First Lady of the United States, Laura Bush, speaking at the 2005 National Youth Summit in Washington, D.C., "I am deeply grateful to all the young people here who have discovered what a privilege it is to make a difference in the life of your communities. By staying committed to your work and sharing your experiences with others, you'll inspire others to dedicate their time and talent and energy to helping in their communities.”

Much of the literature on youth development focuses on family, religious organizations, school and youth leadership organizations as different avenues in which our youth are able to develop their individual character and to become involved in community activities. Different institutions often have many resources available to them that make it easier for youth to find something that fits their personality. These 
institutions help form a child's character and attitude toward service through the relationships that are built by serving in these programs. Jodie L. Roth and Jeanne Brooks-Gunn (2003) indicate that adults are creating an atmosphere where youth are no longer viewed as problems to be managed, but rather as resources to be developed. Youth find these environments to be places where they gain a broader understanding of boundaries, rules and responsibility. Often this is done through serving others in activities including tutoring or mentoring, working with the elderly, providing food for the needy, working in a shelter, and doing yard work. According to Robert Grimm Jr., Nathan Dietz, Kimberly Spring, Kelly Arey, and John Foster-Bey (2005), “fostering environments that encourage volunteer activities are critical to creating a commitment to service and community involvement that will remain with them for their lifetime” (2005, p. 1). Grimm, et al. (2005), also suggests that these institutions are important for developing youth socialization.

Each of these four social institutions, family, religious organizations, school and youth leadership organizations affect our youth. Parents, teachers and communities recognize that we need to take special care in working with our youth. The National Clearinghouse on Families \& Youth (2010) found that youth do need special support to transition successfully into adulthood. Family plays a crucial part in encouraging our youth to participate in community and volunteer service. Parents and extended family are role models as they demonstrate the importance of helping others. Community involvement helps youth develop relationships with their parents, giving them more oneon-one interaction, more communication, and an opportunity for the family to participate 
in activities together. Grimm, et al. (2005), found that youth whose parents are actively involved are more likely to become volunteers themselves. Parents are also more likely to help their children choose youth leadership organizations that support their own family values.

Religious institutions also serve as another social institution that is effective in impacting our youth. They also serve as a strong foundation for developing the need and desire to serve others. Many of these institutions typically have the resources and the man power to build relationships with the youth that encourage them to develop skills of respect, leadership, discipline, and teamwork. Values taught in church may suggest an ethical responsibility to serve. According to a survey provided by the CNCS (2005), the general consensus was that those who attend church tend to serve more than those who are not attending church. The survey also suggested that many served through faithbased organizations or other initiatives outside of the church.

School serves as an additional avenue for socializing children, playing a significant role in providing opportunities for students to serve in the community. According to the CNCS (2010), the Federal government, having a clear appreciation for service and responsibility to enrich the nation, is supporting volunteerism and community service. Having a vested interest in our youth, they have therefore taken the initiative by offering programs through the school to promote skills that are important for personal growth. The government has a long history of involvement in this movement, with support dating back to the early 1900s. Along with the many government programs available to students, many local schools are incorporating community service or service- 
learning as part of their school curriculum. The CNCS (2010) indicates during the 1990s former President George H. W. Bush emphasized the need to administer grants to schools supporting service-learning and other community-based organizations. Sally A. Raskoff \& Richard A. Sundeen state that many schools are encouraging students to serve by providing opportunities while earning class credit, further indicating that students "benefit from increased self-esteem, academic skills, career direction, and community involvement” (1999, p. 75). Educators are seeing the benefit from active participation in these programs.

The Federal government has taken many initiatives to promote volunteering in both the school, and community. After the attacks of September 11, 2001, according to the CNCS (2010), former President George W. Bush supported the initiative of all Americans serving in their community the equivalent of two years (4,000 hours) of their life. This initiative was promoted through the USA Freedom Corps. Former First Lady, Laura Bush, was a leading advocate for Helping America's Youth, one of the many avenues in which the government advocates growth among the youth. During a White House Summit on Helping America's Youth, Laura Bush (2005), along with researchers, policy makers, parents, and community leaders, met to discuss positive ways in which they could go out into their communities and create opportunities to help their local children. It was emphasized that children would benefit in three areas: family, school and community. According to Serve.gov, President Obama’s initiative, United We Serve, launched in the summer of 2009, stresses that we, as Americans, become more united by serving in our communities to help our nation's recovery. 
Youth leadership organizations are another form of social institutions that impact our youth. Ivor A. Pritchard (2001) states that typically these programs offer activities that help meet community needs of various kinds, allowing for a wide range of opportunities for youth to perform tasks without a great deal of specific training. A variety of programs are available to both boys and girls, including Boy \& Girl Scouts, the 4-H Club, and the Boys and Girls Club of America. Most of these programs offer incentives for trying new things, developing new skills, and achieving specific goals. Many resources are available for parents interested in learning more about these programs when deciding what fits their family best.

With so many possibilities, parents strive to find programs that provide an environment, resources, and relationships that help their youth develop in a way that they can contribute to those around them. Parents who desire their children to be involved in community service and other enriching activities will research options that are available to them. Data and research show that one program in particular, The Boy Scouts of America, has done an excellent job at providing research to support their program. The Boy Scouts, along with the research team from Louis Harris and Associates (1998), believe that youth and parents must decide which organizations are best for them by looking at the effectiveness of the program. The Boy Scouts of America believe they are able to help families in this task as they find ways to measure the effectiveness of their program.

Previous research supports the need for quality youth programs. It also supports the idea that there is a wide variety of information available on youth programs. As 
parents attempt to find the perfect fit for their family they may feel overwhelmed by the possibilities. When researching, parents look to the traditional or more widely known programs available to their community. The possibilities are endless, and the research on some is quite thorough as one gains perspective from parents, youth and leaders in different organizations. One program that has received little attention is the Young Marines. Although this program has existed since 1958, no studies have been found that show evidence of parents sharing their views about the program and the impact it is making on their child's life.

According to the Young Marines National website (2006), The Young Marines is a non-profit youth leadership program that strives to promote youth as responsible citizens, learning discipline, leadership, and teamwork. This program, like many others, seeks to develop the character of our youth by focusing on a drug-free life. There is a need to develop a comprehensive study for the purpose of gaining knowledge and insight as to why families choose this unique youth leadership program, particularly the Quantico Young Marines in Quantico, Virginia. Parents who are researching options need to know the benefits and possibly some of the disadvantages of the Young Marines.

\section{Definition of Terms}

Boy Scouts. The Boy Scouts is a youth program that seeks to provide programs and activities that allow youth to try new things, gain an appreciation for others, build self-confidence, and reinforce ethical standards (www.scouting.org, 2010). 
Parents' Perspective on the Young Marines

Community service. Programs that seek to strengthen participants' active involvement in the community and to promote a caring attitude (examples are: tutoring, outdoor clean-up and preparing food for distribution (Prichard, 2001).

Corporation for National \& Community Services. CNCS is a government agency that provides opportunities for Americans of all ages and backgrounds to serve their communities and country through Senior Corps, AmeriCorps, and Learn and Serve America, USA Freedom Corps, faith-based groups, schools and local agencies (CNCS, 2005).

Service learning. Programs that seek to develop participants' critical thinking and problem-solving skills, emphasizing the importance of connecting the service experience to the classroom curriculum and devoting time to student reflection. Community service and service learning are used interchangeably (Prichard, 2001).

Social institutions. Family, religious organizations and schools that foster a sense of community that extends beyond the child's immediate circle (Grimm, Dietz, Spring, Arey, \& Foster-Bey, 2005).

Social socialization. Primary environments where youth form their social networks, learning to interact with others from different backgrounds, form relationships, and develop values and behaviors appropriate for volunteer roles (Raskoff, Sundeen 1999).

USA Freedom Corps. A White House office to coordinate national volunteer efforts in response to the terror attacks of September 11, 2001 by the spurring of several 
Parents' Perspective on the Young Marines

new volunteer programs geared specifically at securing the nation (an example: Citizen Corps Councils) (Bush, 2005).

Volunteering. An activity that has the potential to expand an individual's sense of community through interacting with others from different backgrounds (Grimm, Dietz, Spring, Arey, \& Foster-Bey, 2005).

Young Marines. A youth program that focuses on character building and leadership while promoting a healthy, drug-free lifestyle (youngmarines.com, 2006).

Youth leadership organizations. A variety of organizations in the community, including Boy \& Girl Scouts, the 4-H Club, Kiwanis, and the National Honor Society (CNCS, 2005).

\section{Statement of the Problem}

Parents want to see their youth grow up to be well rounded, healthy adults that are productive members to society. Most parents want their children to have opportunities and experiences that will enhance their own life, while making a difference in the lives of others. Parents play a vital role in seeing that their youth get involved in different activities that meet the needs of both the family and the community. Some will encourage their children to participate in different activities in their church, school and other youth leadership programs. While social institutions offer different avenues that students can participate in to develop their character and strengths, presently no studies exist on parents' views of sending their children to a specific youth leadership program called the Young Marines. It would be beneficial to know how parents feel about the 
program and why they send their children. The availability of so many programs makes it imperative that parents know how this program is different from other youth organizations that are more prominently recognized. Knowing how the students are impacted by this program from the perspective of a parent could influence other parents' decisions to involve their child in the Young Marines. To do this successfully a phenomenological study on the parents' perspective of the Young Marines, focusing on a local unit called the Quantico Young Marines, needs to be undertaken.

\section{Scope of the Study and Delimitations}

This study will examine the level of satisfaction of parents whose children are involved in the youth organization of the Young Marines. Insight into how this particular leadership program operates and the reasons why parents choose it over other programs will be beneficial in decision making regarding their child's participation. Children will not be interviewed during this study. The primary focus of the study is to gain knowledge only from the parents. Parents can provide a great deal of feedback to the reasons behind choosing the Young Marines and the impact it has had on their child. Although the program is nationwide, only about 10,000 youth are in the program compared to the 2,000,000 members served through the Boy Scouts. The focus of this study will be the geographic area surrounding Quantico, VA where the United States Marine Corps is headquartered and it will only include the Young Marines because the Boy Scouts, as well as other programs, have many resources available that provide feedback from parents, leaders, and youth on the effectiveness of their program. Other 
than the general information assessable from the official Young Marines website there appears to be no other studies or research available.

There are several reasons for not interviewing children in this particular study. The variation of ages of youth in the program is wide spread, as well as gender. There are time constraints to this study and interviewing youth would be difficult. Organizing opportunities to meet with those who are enrolled would be take a greater amount of effort and skill because resources are limited, and they may find it difficult to articulate their experiences during the interview because of their age, or length of time in the program. The diversity in knowledge shared may have made it difficult to develop and define the scope of this study.

\section{Significance of the Study}

Research supports the need for effective youth programs [Lerner, R. M. \& Fisher, C. (2000, Jan/Feb), National Clearinghouse on Families \& Youth (2010), and Sullivan, P. J., \& Larson, R., W. (2010)]. This is evident as we see so many different social institutions emphasizing the need for character building. Parents, along with school and the Federal government, have taken great lengths to see that young people are provided opportunities to develop character and leadership skills. As parents explore all their options, this study will give insight into this local organization. The Young Marines offer a program that is an alternative to other youth programs. This study is important because while the Young Marines is a nationwide program, they are not well known. Knowledge 
about this program will help build awareness, giving parents an alternative they may not have known existed.

\section{Methods of Procedure}

This study will be a phenomenological qualitative study on the parents' of participating Young Marines in Quantico, VA. It will involve an inductive research designed with the intent to discover what parents think about the program in which their youth are involved. It will give parents an opportunity to voice their opinions, while allowing the reader to see the effectiveness of the program from their perspective.

It will be necessary to collect data in a variety of ways. Participation in activities arranged by the Quantico Young Marines whether it be a scheduled meeting or a community service activity will allow firsthand observations. Data will be recorded and information in field notes will be used for reference in the study. Materials from the national organization will be used to help collect data that would be pertinent to the study as insight and knowledge garnered from the research is shared. In-depth interviews with parents who have children in the Quantico Young Marine program will help develop thoughts, beliefs, reasoning, and motivation of the parents. Data will be collected through open and semi-structured interviews. An interview protocol will be used in the interviews so the general topics covered are shared among all interviewees. All interviews will be taped and then transcribed to facilitate a qualitative analysis of common trends within the programs. 
As research is done, only parents involved with the Young Marines in Quantico, VA will be interviewed. Maximum variation sampling will be used to gain a perspective from a variety of parents who have youth participating based on how long their child has been in the program and the age of the child. Sampling will be conducted in this manner because the child's ability to participate could vary and the impact might differ based on age. Insight gathered only from parents who were new to the program would not be as beneficial as gathering information from parents who have been a part of the Young Marines for an extended period of time and could share experiences from the program. Also, interviewing parents who have younger children may not be able to give firsthand accounts of the program, sharing about the positive and negative effects of the drug resistance program, leadership skills, and other areas emphasized by the program. Interviews will be terminated when information extrapolated from the interview transcripts show repetitious details. Data collected will be used in the analysis to enhance the findings, sharing the positive and negative of the program.

Comparisons from the interviews will be done after transcriptions of all the tapes are complete. As comparisons are made, coding of the data will include phrases, ideas, and motivational words that are commonly referenced among the interviewees. As the analysis of the data is done, generalizations about the findings will be made. Common themes throughout the interviews relating to motivational factors when choosing the Quantico Young Marines will be reported in this study. 


\section{Chapter Two}

\section{Plenary Literature Review}

Much of the literature focuses on family, religious organizations, schools, and youth leadership organizations as different avenues our youth use to develop individual character and build community responsibility. Research identifies a large range of positive characteristics that are beneficial. A variety of youth organizations, including the Young Marines are examined.

The purpose of this study is to gain a better understanding of parent's perspective on the Young Marines as a youth leadership organization provided by the community in which they live. The main emphasis of the study is to acquire the parent's view on how meaningful participation in the program is to their youth. The literature has found a great support for out-of-school youth development programs. Effective programs enhance skills such as respect, leadership, organization, and volunteerism. Researchers, teachers, and organizational leaders alike have been able to identify several characteristics that are apparent in successful programs for young people. Overwhelmingly, the research shows through findings, such as in the Boys and Girls Club of America, Boy Scouts of America and the 4-H Club, that programs like these are promoting positive self-concepts that are making an impact. 
Parents' Perspective on the Young Marines

\section{Youth Character and Development}

In Components and Characteristics of Youth Development Programs: The Voices of Youth-Serving Policymakers, Practitioners, Researchers and Adolescents, Jennifer Brown Urban sought to gather a set of constructs that were common among youth development programs. Urban (2008) points out that there have been many attempts to articulate a unified definition of youth development as the popularity of the youth leadership programs continues to grow. A unified definition of youth development would allow youth development programs to be assessed in a more effective manner. A variety of lists or criteria have begun to emerge as the field of youth development continues to grow.

Urban used this study to compare and contrast ideas from four different groups. She attempted to have the voices of policymakers, practitioners, researchers and adolescents all be heard. The study’s objective was to use a community-based participatory approach to gain key characteristics of youth development programs. Concept mapping was the primary method used, allowing for qualitative and quantitative data to be utilized. Policymakers, practitioners and researchers were contacted through a listserve and/or referrals by colleagues, and then later contacted by e-mail. Youth were recruited from two different youth programs in the central New York area.

Through brainstorming and group sessions a variety of statements were prepared and used in the structuring phase which formulated the concept map used in the study. All data was rated by importance and by similar matrices creating a concept map that 
generated common threads through the original statements used in the study, along with other ANOVA and chi-squared analyses.

Results suggest there is a broad consensus across the four groups used on the key components. The common threads found in the matrices done in the concept mapping were similar and overlapped with those found by others (Roth \& Brooks-Gunn, 2003; the Search Institute, 2010; \& Lerner, 2000). The key components found were: an empowering youth-friendly atmosphere; youth leadership opportunities; opportunities for life skills development; promoting individuality and connectedness; innovative, strengthbased principles; a welcoming environment and family engagement; high expectations of youth workers; program structure; broad-based community involvement; and ongoing program monitoring and assessment.

“It wasn't until the turn of the $20^{\text {th }}$ century that society began to recognize that youth need special support to transition successfully into adulthood” (National Clearinghouse of Families \& Youth, 2010, p.1). As research has developed over the years, the emphasis has been on gaining a better understanding of our youth in the area of positive youth development. National Clearinghouse of Families (2010) indicate that as the growing concern for juvenile delinquency increased in the 1950s the government began to play a greater role. As shown in the article, Putting Positive Youth Development Into Practice: A Resource Guide, compiled by National Clearinghouse on Families \& Youth, "early interventions focused on crisis management," then the attention moved to “prevention” and now they aim to look at "positive reinforcement” (p.1). 
"One of the most comprehensive, and frequently cited, works comes from The Search Institute" which has put forth an extensive list of what they consider “developmental assets” (National Clearinghouse of Families \& Youth, 2010, p.1). This list consists of character necessities that come from the "outside world of community and family" and from "inside the youth themselves" (p.1). Some of the characteristics that have been listed under The Search Institute’s 40 Developmental Assets are support, empowerment, boundaries and expectations, constructive use of time, commitment to learning, positive values, special competencies, and positive identity (Search Institute, 1997). The Search Institute has dedicated time and money to researching and developing this exhaustive list of developmental assets.

Research by the Search Institute has shown that having a greater number of these developmental assets reduces a young person's tendency toward alcohol use, tobacco use, illicit drug use, antisocial behavior, violence, school failure, sexual activity, attempted suicide, and gambling. Beyond simple prevention, developmental assets have also shown to help youth "thrive" - to overcome adversity, delay gratification, succeed in school, value diversity, help others, demonstrate leadership, and be physically healthy (Putting Positive Youth Development into Practice, www.ncfy.hhs.gov, 2010, p.3).

The article, What Exactly Is a Youth Development Program? Answers from Research and Practice, Jodie L. Roth and Jeanne Brooks-Gunn sought to examine three defining characteristics of successful youth programs identifying goals, atmosphere and 
activities. Seventy-one different organizations from local, state, and national groups responded to a survey of open ended questions. Roth and Brooks-Gunn (2003) defined successful youth programs as being one that was supportive, enriching, and challenging.

Through the survey they were able to distinguish several characteristics that were in support of research that endeavored to protect adolescents from juvenile delinquency while promoting individual strengths. Roth and Brook-Gunn's research aligned with other well-known research groups regarding youth and promoting positive characteristics. Youth programs are places where youth can expand their horizons when given opportunities they might otherwise not have (Roth, Brooks-Gunn, 2003; National Clearinghouse of Families \& Youth, 2010). Richard M. Lerner, Celia B. Fisher, and Richard A. Weinberg (2000) state that the 5 C's of healthy development are competence, connection, character, confidence and caring/compassion. Through essential functions, proper resources, and these commonly known 5 C's incorporated into their lives, youth will "thrive" as opportunities for them to contribute, or "give back" to the community come available (Lerner, et al., 2000, p. 15).

The popular 5 C's are seen throughout many organizations, including a popular national organization known as the Congressional Youth Leadership Council. Youth are chosen every year by local teachers to participate in enrichment conferences based on character and academic achievement. The main objective of the Congressional Youth Leadership Council (2010) is to "work with young leaders from schools and communities helping to sharpen and perfect skills that will help prepare them to become tomorrow's 
business, political, and educational leaders" (pamphlet, "Benefits of Attending \& Parent Information," back page).

Programs provide a great way for youth to build core values that can be carried over to adulthood. In Connecting Youth to High-Resource Adults: Lessons from Effective Youth Programs by Patrick J. Sullivan and Reed W. Larson, their investigation into seven successful urban, leadership, and arts programs, interviewing leaders and 71 ethnically diverse youth over three to four months to learn from their experiences. Youth were exposed to successful professional business opportunities that gave insight into the adult world that were somewhat unfamiliar to them. Observations and analyses were made on what programs were creating youth-adult interactions, along with what experiences and resources youth gained from these interactions.

Sullivan and Larson (2010), state that as youth approach adulthood, they do benefit from meaningful youth-adult relationships outside of school. To ensure that the events went well, leaders organized structured activities and facilitated opportunity for learning. This was done through a variety of activities including presentations by experts, solicitation, and shared projects with adults from the community along with teaching and/or training youth before and after activities. They characterized that the majority of students found the experiences to be worthwhile; however, some participants suggested that sometimes "they were not taken serious and given more leadership roles" (Sullivan \& Larson, 2010, pg. 110-111).

This particular article indicates that youth programs offer resources rich in diversity for youth. Youth make contact with new people gaining access to the adult 
world; obtain information, socialization, and opportunities to serve in areas where they are able to give back to the community. As Sullivan and Larson (2010) point out, adult leaders often become mediators between youth, helping them with problem solving, and build self concept. As society strives to protect our youth from juvenile delinquency and other problems, youth programs look to values that define us as a person (Roth, BrooksGunn, 2003; National Clearinghouse for Families \& Youth, 2010).

As youth obtain exposure to a variety of experiences outside of school, positive development occurs. First-hand experience gives youth the opportunity to be mentored by adults who can provide pertinent information to their future as they seek to grasp the many resources available to them as they become adults. Sullivan and Larson indicated that these "resources that are typically out of reach for adolescents, especially to lowincome urban youth" are beneficial as they plan for their future (college, careers, and adulthood) (2010, p.117).

As many realize there are many ways in which our youth can be influenced by society as it addresses the need to develop character, values, attitudes, and service to the community. Although volunteer, mentoring and youth programs are growing nationwide, Roth \& Brooks-Gunn (2003) emphasize that availability, cost, transportation, and interest limit many children when they are not in school. Another limitation is the need for adults to be more actively involved. Unfortunately, according to Jean E. Rhodes, G. Anne Bogat, Jennifer Roffman, Peter Edelman, and Lisa Galasso (2002), families, schools, and communities have changed in ways that has dramatically reduced the availability of adults to fill the role of mentors to our youth. This is especially true in 
urban areas. As middle-class families leave the city to suburbia areas, there are fewer role models and leaders to help mentor youth. The detachment of the family, causing parents to both work and be absent from the home, has created an atmosphere where adults are absent from the social network of youth programs. There is also a disconnection between youth and adults as youth struggle to make connections with mentors because the relationship does not last long term.

Another issue parent's face is determining what programs provide an environment that will most effectively meet the needs of their youth. Parents are struggling to find positive ways to develop well-rounded, healthy youth as their children look to peers, media and other sources for acceptance. Rhodes, et al. (2002), states that children in urban communities are now more disconnected as the middle-class adults who traditionally served as leaders or role models have moved away from the cities. This further suggests that youth have to rely more heavily on the school system to truly benefit from individual growth and to develop a desire to serve in the community.

\section{Successful Youth Programs}

In one particular study done for the 4-H Club, researchers explored how the positive impact of 4-H varied among the youth. According to Jason Hedrick, Greg Homan and Jeff Dick (2009), there was an improvement in the youth's communication skills, increased ability to respond to responsibility, and more acceptance of differences among the group. As Barry A. Garst and F. A. Bruce (2003) found, parents recognized the ability of the program to give youth an opportunity to acquire life skills, make friends, 
and become more independent. From parents' perspective, youth were given the opportunity to gain multiple strengths that will carry over for life.

The goal of Boys \& Girls Clubs of America (BGCA), a national organization, is "to inspire and enable all young people, especially those from disadvantaged circumstances, to realize their full potential as productive, responsible and caring citizens" (BGCA, 2007, p.2). Youth who have a poor self-concept are struggling with a variety of problems/issues that contribute to an attitude reflected by negative behaviors. According to Dawn Anderson-Butcher and Scottye J. Cash (2010), findings from this particular study with the BGCA, indicate that small changes in self-concept could potentially produce important changes in negative behavior helping youth to make better choices. BGCA, like other programs, serves an important role in the lives of youth, whether or not the focus is on the disadvantaged.

Boy Scouts of America (BSA), another national organization, also aims to work very closely with youth to develop leadership skills for the future. Like the Young Marines, BSA wants to have a lasting impact on the future of our youth. The positive things taught through this program are things leaders believe are essential, and hope the skills taught here stay with them for a lifetime.

According to the BSA national website (2010), it claims to be a prominent valuesbased youth development organization that provides educational activities and life-long values while having fun. The program focuses on character building, responsible citizenship, and physical fitness. The national website (2010) states that "The Boy Scouts of America believe that helping our youth is a key to building a more 
conscientious, responsible, and productive society”. As youth struggle to meet the challenges of everyday life, the BSA want to reach out to youth, giving them the resources necessary to be successful by teaching them values that will help them reach their full potential. The BSA focuses on patriotism, community service, learning new things, leadership, and being productive. They also wear a uniform that makes them distinct from other groups and closes the gap on socioeconomic issues. "Be Prepared" is the Scout motto.

Louis Harris \& Associates conducted a study on the BSA, to see whether they were achieving their goals and how well they were doing it. According to the study, in 1995 BSA found that men and boys who were involved in the Boy Scouts at one point in their lives credited their success on the experience they had in the program. The aim of the study was to indentify some of the reasons youth were having positive outcomes. Some of these included strong personal values/character as well as ethical/moral values, self-worth, nurturing relationships, experiences, and social adeptness.

\section{The Young Marines Organization}

As an organization, the Young Marines has been in existence since 1958. The Young Marines national website provides great detail behind its history and its future working with youth. Although this program is nationwide, approximately 10,000 youth participate in the program compared to the 2,000,000 members served through the Boy Scouts. The Young Marines has units in 46 states, the District of Columbia, Germany, Japan, Australia and affiliates in a host of other countries. The Young Marines National 
website (2006) states that it is a youth program for boys and girls, eight through completion of high school, focusing on education and service through the promotion of mental, moral, and physical development of its members. The Young Marines program is the focal point of the United States Marine Corps’ Youth Drug Demand Reduction program. The continued focus through all the age groups is teamwork, character building, leadership, and promoting a healthy, drug-free lifestyle.

The motto by which the adult leaders live is "Strengthening the lives of America's youth". The leaders who work closely with the youth encourage them to be an example that others can follow. Many of the adult registered leaders are former, retired, active duty or reserve Marines who believe that the values they learned as Marines had a positive effect on them. Although many of the volunteers are associated with the Marines in some way, it is not required and volunteers are always welcome, regardless of whether their background is in the Armed Forces or not. It is believed that "it is through these caring adults that Young Marines learn the inner values of Honor, Courage, and Commitment" (www.youngmarines.com, Fact Sheet, p. 1). The Young Marine Obligation, which the youth are required to memorize states:

From this day forward, I sincerely promise, I will set an example for all other youth to follow and I shall never do anything that would bring disgrace or dishonor upon my God, my Country and its flag, my parents, myself or the Young Marines. These I will honor and respect in a manner that will reflect credit upon them and myself. Semper Fidelis (Young Marine Basic Guidebook, p BYM-2-6). 
The Young Marines emulates the United States Marine Corps with its ethos of honor, courage, and commitment. Youth are taught that consistency and belief in leadership by example are central. You can recognize Young Marines by their woodland camouflage uniform; an old camouflage uniform that Marines use to wear. The Young Marines also use the enlisted ranks of the U.S. Marine Corps; Private through Master Gunnery Sergeant. Mr. Joe Venable, Deputy Director, says “this program gives youth leadership training, experience setting goals, and accomplishing objectives within their community. We want them to set the example for all youth to follow. At no time is this program used as a recruiting tool for the U.S. Marine Corp (personal communication, December 06, 2010)!”

According to the Young Marine Fact Sheet provided by the Young Marines national organization, the youth are required to undergo a 26-hour orientation program, affectionately called "Boot Camp”. This orientation can be spread out over several meetings or combined and completed during a five day concentrated "Boot Camp" where youth stay at a designated facility for the duration. During the orientation program, “youth learn general subjects such as history, customs and courtesies, close order drill, physical fitness, and military rank structure,” as well as having opportunities to work on ribbon achievement (www.youngmarines.com). At the local Young Marines unit in Quantico, Virginia, many, but not all, youth may have the opportunity to stay on the Quantico Marine Corp Base, while accomplishing “Boot Camp” objectives. They stay in 
the barracks, eat in the "mess hall,” participate in "fire watch" with a battle-buddy, and experience the unique privilege of working closely with active Marines on drill.

After completing "Boot Camp," the new recruits are given Young Marine uniforms that include a cover, blouse, trousers, and boots. As youth work through the program, they continue to learn new skills while earning both ribbons and rank. According to the website, Young Marines are able to earn ribbons for a variety of achievement areas, which include but are not limited to leadership, community service, swimming, music, academic excellence, first aid, good conduct, personal commendation, and drug resistance education.

The National Young Marines supports a variety of activities. One program in particular is SPACES: the Young Marines National Summer Programs of: Adventure, Challenges, Encampments, and Schools (SPACES).

Schools consist of leadership courses. Adventures, have a historical emphasis and are designed with the younger child in mind. In contrast, older Young Marines can participate in Challenges. Challenges consist of training in areas such as survival skills, wilderness training, and water-based activities. Young Marine encampments provide the opportunity for Young Marines of all ages to gather together and train as a large unit of up to 700 youth at a time. (Young Marines Fact Sheet, pg. 2) 
One special event held annually by the Young Marines is the Young Marines Veterans Appreciation Week. According to the Fact Sheet the purpose of the campaign is to challenge youth to dedicate personal time with veterans, demonstrating their appreciation for the service veterans have given to our country. Although there are many ways to show appreciation, such as writing thank-you letters and cleaning up a veteran's yard, the local Young Marines organization located in Quantico, Virginia participate in a ceremony for fallen service members on Veterans Day and clean a portion of the National Quantico Cemetery twice a year.

Honoring our veterans does not stop with the Young Marines Veterans Appreciation Week. Units nationwide spend countless hours honoring veterans, past and present. This is done through a variety of activities. Youth participate in Memorial Day and Veterans Day parades, flag ceremonies, and conduct color guards for special events at memorials. The Young Marines take the time to place flags at grave sites in select cemeteries, honoring the fallen by calling out their name and saluting. Youth also take part in paying special tribute to fallen Marines who have served in Iraq and Afghanistan during memorial ceremonies.

The Young Marines is an organization that started out "with one unit and a handful of boys in Waterbury, Connecticut”. A group of men, a part of the Brass City Detachment of the Marine Corp League, who believed that the values that had been instilled in their lives while in the Marines Corp were worth teaching to others began in April of 1959. The original founders were Roland (Rollie) T. Hamel, Sr., Raymond (Ray) L. Bozzuto, Anthony (Tony) Szantry, and Arthur (Art) Corcoron. 
Roland Hamel, an original founder, stated that “while meeting in Art Corcoron’s attic, decided to come up with a program for their sons and a few of the younger boys in the area" (Young Marines - Our History: Strengthening the Lives of America's Youth, 2010). After being informed that they would not be able to start their own Boy Scouts Unit, they decided to organize a group of young boys whom they could teach and train in the values they had learned in the Marine Corps. Initially, they began the unaffiliated organization with 13 boys who marched in the local Memorial Day parade. The men got a few uniforms and started drilling with the boys. Tony Szantry, an original founder, states that "the kids got to liking it, and before you knew it they had a big gang of them coming down, all falling in” (Young Marines - Our History: Strengthening the Lives of America's Youth, 2010). As Ray Bozzuto says, "if they are willing to put on the uniform, we were willing to teach them" (Young Marines - Our History: Strengthening the Lives of America's Youth, 2010). These men were passionate about working with America's youth, wanting to motivate, guide, and instruct the next generation. These young boys were taught discipline, respect, taking charge, drilling, patriotism, life skills to keep them straight, and many more things. Art Corcoron stressed that they were not grooming them to become Marines.

The vision of the original four founders was admired by so many in the community that it was expanded. Membership grew from 16 to 300 by 1960. They expanded their activities by including camping trips and a baseball team. It was in 1965 that the Marine Corps League official charter was signed. After many other accomplishments over the years, in 1993 the United States Marine Corps chose the 
Young Marines as their focal point for their youth Drug Demand Reduction Program. Lt. Col. Mike Kessler, hired as the National Executive Director in 1999, shares how the Young Marines were honored with the $1^{\text {st }}$ Fulcrum Shield Award given by the Secretary of Defense in 1991. The Fulcrum Shield Award is awarded to those who show excellence in youth anti-drug programs for their organization. The Young Marines has received this award a total of three times to date. In 2009 the Young Marines celebrated their $50^{\text {th }}$ anniversary.

What started out as a small group of boys is now open to all youth, boys and girls, ages eight through completion of high school. The Young Marines seek to continue to strengthen the lives of the America's youth and can be found in roughly all 50 states, the District of Columbia, including international units in Germany, Japan, and Australia. 
Table 1

Number of divisions and states being served through the Young Marines

\begin{tabular}{|c|c|}
\hline NUMBER OF DIVISIONS & STATES SERVED IN EACH DIVISION \\
\hline $\begin{array}{c}\text { Young Marine Division 1: } \\
\text { (42 YM Units) }\end{array}$ & $\begin{array}{c}\text { Maine / New Hampshire / Massachusetts / } \\
\text { Connecticut / New York / New Jersey / } \\
\text { Pennsylvania }\end{array}$ \\
\hline $\begin{array}{c}\text { Young Marine Division 2: } \\
\text { (37 YM Units) }\end{array}$ & $\begin{array}{c}\text { Maryland / Virginia / West Virginia / Delaware / } \\
\text { District of Columbia / Kentucky }\end{array}$ \\
\hline $\begin{array}{c}\text { Young Marine Division 3: } \\
\text { (50 YM Units) }\end{array}$ & $\begin{array}{c}\text { N. Carolina / S. Carolina / Georgia / Florida / } \\
\text { Tennessee }\end{array}$ \\
\hline $\begin{array}{c}\text { Young Marine Division 4: } \\
\text { (48 YM Units) }\end{array}$ & $\begin{array}{c}\text { Arkansas / Colorado / Kansas / Louisiana / } \\
\text { Mississippi / New Mexico / Oklahoma / Texas / } \\
\text { Wyoming }\end{array}$ \\
\hline $\begin{array}{c}\text { Young Marine Division 5: } \\
\text { (47 YM Units) }\end{array}$ & $\begin{array}{c}\text { Indiana / Illinois / Iowa / Michigan / Minnesota / } \\
\text { Missouri/ Nebraska /N. Dakota / Ohio / S. Dakota } \\
\text { / Wisconsin }\end{array}$ \\
\hline $\begin{array}{c}\text { Young Marine Division 6: } \\
\text { (59 YM Units) }\end{array}$ & $\begin{array}{c}\text { Arizona / California / Idaho / Montana / Nevada / } \\
\text { Oregon / Utah / Washington }\end{array}$ \\
\hline $\begin{array}{c}\text { 285 Total Young Marine Units with two in Japan and one in Germany } \\
\text { And two in Australia }\end{array}$ \\
\hline
\end{tabular}

Provided by the Young Marines National Headquarters (January, 2011)

Although empirical research is limited, interest in these programs is growing as they offer rich resources as youth transition into adulthood (Amodeo \& Collins, 2007; Grimm, et al., 2005; Roth \& Brooks-Gunn, 2003; National Clearinghouse on Families \& Youth). Literature supports diverse youth development programs that are thriving, offering common threads that stand out in prevalent programs in the community. Youth programs offer an opportunity for personal development, as well as an opportunity to give back to the community. Parents encourage participation in programs that prove to 
be useful and effective; therefore it is prudent to investigate what qualities or experiences parents see as they interact with their youth in the Young Marines.

Youth can be influenced by society as it addresses the need to develop character, values, attitudes, and service to the community. Parents face a difficult task of determining what programs provide an environment that will most effectively meet the needs of their youth. As this study develops, the goal is to offer an alternative to programs that are readily available. 


\section{Chapter Three}

\section{Methodology}

This qualitative study is based on a phenomenological outlook from the parents’ of participating Young Marines in Quantico, VA during the year of 2010-2011. No studies were found that relate to the Young Marines, therefore a phenomenological study emphasizing a variety of input from parents' perspective that could be utilized for future research and as a reference. It involved an inductive research design with the intent to discover what parents thought about the local program in which their youth were involved. By conducting personal one-on-one interviews, parents were given an opportunity to voice their opinions, while allowing the reader to see the effectiveness of the program from their perspective. Although a case study would have been effective, conducting in-depth research on only two or three individuals was not the intent; therefore a broad analysis of the program as a whole was undertaken.

\section{Population and Sample}

In conducting the interviews for the research, only parents involved with the Young Marines in Quantico, VA were interviewed. This particular unit has been in existence since 1998. Initially, the goal was to use maximum variation sampling. This would have allowed the interviewer to locate individuals, selecting parents based on how long their child has been in the program and by the age of the child. Sampling would be conducted in this manner because the child's ability to participate could vary and the 
impact might differ based on age. Contact was then made by e-mail with all registered families in the unit informing them of the research being conducted.

As research progressed, it was clear this method was not productive. Although there are about 62 youth currently registered as Young Marines, approximately 25-30 attend on a regular basis. As research progressed, it became clear maximum variation would not be productive. Many did not feel comfortable with being a part of a taped interview. With this in mind, all parents who currently had a child serving in the Young Marines were considered potential study participants in the interviews. Contact was made again by e-mail to all 54 registered families, asking that if they would like to be interviewed that they contact me. A total of 18 parents signed consent forms and were interviewed, showing a representation of 33\% response rate.

Thirty-three percent of the final sample included both male and female. Seven males and eleven females were interviewed. Study participants had children ranging from the ages of eight to eighteen years with an average age of 12.3 years. All interviews were conducted during a two month time frame. As presented in Table 2, demographics of the youth reflect the characteristics of the youths participating in the Young Marines at large, with little variation from those who participate nationwide in Table 3. 
Parents' Perspective on the Young Marines

Table Two

Demographics of Young Marines located in Quantico, VA as of Jan. 2011

\begin{tabular}{|c|c|c|c|}
\hline \multicolumn{2}{|c|}{ AGE } & \multicolumn{2}{c|}{ GENDER } \\
\hline $8-9 \mathrm{yr}$ & 10 & MALE & FEMALE \\
\hline $10-12 \mathrm{yr}$ & 22 & & 11 \\
\hline $13-15 \mathrm{yr}$ & 21 & 51 & \multicolumn{2}{c|}{ Total of 62} \\
\hline $16+\mathrm{yr}$ & 9 & \multicolumn{2}{|c|}{} \\
\hline
\end{tabular}

Table Three

Young Marine Demographics in the US as of January 2011

\begin{tabular}{|c|c|c|c|}
\hline \multicolumn{2}{|c|}{ AGE } & \multicolumn{2}{c|}{ GENDER } \\
\hline $8-9 \mathrm{yr}$ & 860 & MALE & FEMALE \\
\hline $10-12 \mathrm{yr}$ & 2875 & 6433 & 1439 \\
\hline $13-15 \mathrm{yr}$ & 2952 & \multicolumn{2}{c|}{ Total of 7872 } \\
\hline 16 plus & 1185 & & \multicolumn{2}{c|}{} \\
\hline
\end{tabular}

Provided by the Young Marines National Headquarters (January, 2011)

\section{Procedure}

A pilot study was conducted at the onset of the research project. Four families were approached and asked to take part in an interview that would be used as part of research on the Quantico Young Marines. After completing the initial interviews, it was determined that some questions needed to be reconstructed, as order of questioning did not flow well and the opportunity for more open-ended questions was lacking (APPENDIX B). 
Based on the pilot study, research was conducted through personal interviews and questionnaires, observations, and data compiled from the website and personnel from the National Young Marines Headquarters. The data analysis was collected in a way to bring a triangular effect to the phenomenon. Firsthand observations were made while the Young Marines participated in a variety of scheduled activities. During meetings and community service activities several things were observed. Some of these things included the excitement seen from the youth, diligence among the group as they worked on protects, and desire to get drills right and color guard successfully flowing. There was observation of youth interacting with veterans, teamwork on community projects, cleaning the cemetery, a parade, participation in drug awareness classes, and kids getting excited over building bikes for other youth in need. Data was recorded through interviews and information gathered through the firsthand observations were recorded in field notes and used as reference in the study. This was important as it helped show that what parents were saying in the interviews were seen in the meetings that were observed.

Materials from the Young Marines National Headquarters were also used to collect data that would be pertinent to the study. The website provides a wealth of information on the Young Marines as a youth organization. The website, along with confirmation through personnel at headquarters and a DVD provided by the National Headquarters, gave details about the focus of the Young Marines, along with the volunteers who serve the youth, and the training the youth receive when they join. The mission of the Young Marines is clear - teaching youth to be responsible citizens and have a healthy, drug-free lifestyle. 
In-depth interviews with parents who have children in the Quantico Young Marine program helped develop thoughts, beliefs, reasoning, and motivation of the parents. Data was collected through open and semi-structured interviews (APPENDIX C). An interview protocol was used in the interviews ensuring that the general topics covered were shared among all interviewees. Several questions were asked, among them were 1) What are parents saying about other youth programs? What about the Young Marines? 2) What character and leadership skills are being encouraged? 3) What knowledge is already known about the Young Marines? 4) What experiences do the Young Marines have that help shape them as individuals? 5) What are parents seeing as a result of these experiences?

All interviews were taped and transcribed to facilitate a qualitative analysis of common trends within the programs. In an attempt to promote validity for this study, participants were contacted for verification and feedback. Low-inference descriptors were also used in the results. During the interviews, participants were given opportunity to disconfirm expectations of the phenomenon by sharing details that they felt were not satisfactory to them. 


\section{Chapter Four}

\section{Results \& Analysis}

Research supports youth development programs as beneficial. For example, multiple studies show positive development taking place when youth acquire a wide range of internal and external assets that aid in the healthy development of youth mentally, socially, and physically. A comprehensive study listing "assets” that are crucial for youth were compiled by the Search Institute (www.search-institute.org, 2010). Other researchers have articulated similar concepts that support attributes that are necessary if we seek to have them "thrive” in today's society (Lerner, 2000). Through the support of the Federal government, the state and local communities working with the schools and community organizations are all making attempts to impact the lives of youth in a positive way.

This phenomenological study examines the satisfaction of parents whose children are registered in the Quantico Young Marines. Numerous parents with youth in this program participated in interviews that consisted of the same general open-ended questions, along with specific questions. These interviews, along with observations made during activities, and data gathered from other resources, gave a more comprehensive view of the Young Marines as a local youth organization in Quantico, Va. Insight into how the program operates and why parents choose it over other local programs were discussed. Common threads developed as interviews were completed: a) reasons why 
their child was in the Young Marines and their role in the decision b) parents' perspective of the program c) the impact it has had on their child d) details into why parents and youth are giving back to the community e) views on youth led program verses adult led program.

Until now, little has been clear about the essence and structure of the Young Marines. The results that were found are broad in nature, but bring a new perspective that has not been currently available. This program represents a very limited sample size, therefore it is important to emphasize that data collected from these parents does not represent the National Young Marines as a whole. In-depth investigation of parents’ views and knowledge of the program will help to further examine real-life dynamics of the program and generate more in-depth research. Constructs that emerged from interviews and data from other sources are outlined below.

\section{Decision to Join, Role in Decision}

Parents gave similar reasons for participation in the Quantico Young Marines including choice of the child, parent's decision, and joint decision. Nearly all the parents said that the child chose to join based on the knowledge that they had about the program from a friend or their personal interest in the military. Parents shared how other youth had informed their child of all the fun activities they were doing such as parades, military drills, and special events (example: color guards, visiting historical sites or going to a site to observe the Marines performing operations using amphibious vehicles). Some youth observed the participation of Young Marines in a parade, liked the uniforms, and had 
their parents look into it. One mother shared that while looking into programs at a nearby military base, she inquired into a program called the Naval Sea Cadet Corp., however, her son was not old enough for this particular program. After finding the Young Marines, she was excited because it included a wider age range of children.

Parents indicated a variety of ways they learned about the program. Friends, colleagues or other parents who had children in the Young Marines sparked their interest in the program. An ad in the newspaper prompted some parents to further investigate, others were intrigued by open house events offered by the unit, and some spent time researching the website.

Knowledge about the Young Marines can easily be found at the National Young Marines website (www.youngmarines.com). Parents, youth, and the volunteers can navigate through the website finding things that apply to them. At the top of the home page the mission of the program states “Strengthening the lives of American’s Youth”. Parents can easily locate units in their area by putting in their zip code. There is also a section dedicated to frequently asked questions and answers along with a phone number to headquarters where you can talk to someone directly. Youth are given an area for them to research ways they can develop skills, look for special programs, sign up for scholarships, earn ribbons, and see their progress in earning rank by reviewing their guidebook. Each commander for the unit takes the time to record all data in the website for youth to view when providing the appropriate password for their account. Volunteers are able to locate data, communicate with other leaders, and find things that there unit may want to get involved in. 
The National Executive Director, Mike Kessler, has recently released another way parents and youth can stay in touch with the Young Marines by announcing a new broadcast called Young Marines News Network (YMNN). This new online resource will be used as another tool, like the Esprit magazine, for news from other units around the country to be heard on a quarterly basis. Using this internet tool will give youth another opportunity to pitch their ideas and stories to be shard on YMNN as national news on National Young Marines website.

Many parents indicated that it was the fun activities, the military uniform and drills, the history, structured environment, strong adult leadership, and development of skills emphasized in the program that drew them to this program. In a few cases behavior issues at home and school were a factor in parents' decision to enroll their child. Parents looking for additional support and a structured program felt the program would be beneficial to their child's overall development. One mother shared some of the social and behavioral difficulty her child was experiencing and felt that this program would "get her back on track to be more respectful. This program is structured. It is teaching her leadership skills and teaching her not to be a follower and to use her own mind (personal communication, November, 13, 2010).”

Several of the parents stated they had tried other programs, but felt the other programs were not as organized, adult supervision was often lacking, child refused to wear the uniform, and/or the program did not meet parents’ specific needs. "The Young Marines seems to have more of a purpose to the activities,” said one father who had been involved in other youth programs with his son (personal communication, November 20, 
2010). One mother pointed out that with other programs "it seemed like there were too many kids and never enough adults to assist” (personal communication, November 13, 2010). Three parents stated they were involved in the Young Marines along with another program, sharing that they felt what was missed in one program was covered in the other program, which kept their child balanced and focused.

With a wide variety of youth programs available choosing one can be difficult. Some parents indicated that they want to keep their youth busy, and being involved with two different programs works for them. As indicated before, what is missed in one program is offered in another program. The Young Marines offer something that is unique from most. The Young Marines is the focal point for the U.S. Marine Corps Youth Drug Demand Reduction Program making it unique from other programs. Other programs are teaching boys and girls to say "no" to drugs, but this program makes it an integral part of their program. In comparison to other programs, they also offer individual and group awards teaching team work. It is possible to say in comparison to other programs that the activities offered for outdoor field skills and knowledge is unique from other programs. The challenges and rewards gained from the experience of learning outdoor safety, survival and hiking skills will be useful as the youth mature. Also, while promoting healthy living, youth are encouraged to help others by joining others in community service. 


\section{Parents' Perspective of the Program}

Parents recognize the significance of the Young Marines. Consistent with the website where it states that the Young Marines strengthen the lives of youth, promoting a drug-free lifestyle, teaching self-confidence, academic achievement, honoring veterans, good citizenship, and community service (www.youngmarines.com), parents that were interviewed identified these same strengths. Although some were not able to give specifics, the majority of parents were able to identify characteristics that stand out about the local organization, along with examples. Parents felt that the volunteers were an encouragement to their youth, boosting their self-esteem. Volunteers go out of their way to ask about school, grades, and helping with homework. Parents like how the leaders not only encourage the youth to get involved with community service, but also help when getting out in the community for projects. One adult explained, "It offers more than I thought it did. In the beginning I thought it was going to be just like drilling and physical training and stuff like that while in uniforms (personal communication, December 06, 2010).” This same mother also said, "the program offered much more than that, it offered physical fitness, structure, encampments, and different public events where youth met prominent people”. Among the list of strengths that parents indentified as being important during interviews were: drug-free program, discipline, camaraderie, teamwork, structure, respect, self-confidence, leadership, core values of the Marine Corp, activities with a purpose, responsibility, accountability, community service, history, and the love of country. 
The national organization states that "the mission of the Young Marines is to positively impact America's future by providing quality youth development programs for boys and girls that nurtures and develops its members into responsible citizens who enjoy and promote a healthy, drug-free lifestyle” (www.youngmarines.com). Most parents were aware that there is a strong emphasis on educating youth about drugs and their effects on a person. Parents said that during scheduled local meetings the youth attend drug demand reduction classes that are taught by registered adult leaders who are police officers or Marines. Sometimes a special guest comes to work with the youth in this unit. The Gang Task Force, supported by a detective from each of the four counties in the area, along with the State Police and the Federal Bureau of Investigations came to meet with the unit to teach them about gangs, drugs, and the consequences of doing drugs, as well as bringing their working dogs along with them. The Young Marines guidebook indicates that they will spend a minimum of 3 hours each quarter completing the performance objectives for the drug reduction program. Parents also shared that although schools are teaching these things, it is important for the child to hear about it at home and in other structured environments such as the Young Marines.

The National Young Marines supports the drug reduction program and continues to find ways to increase the awareness of drugs. Mr. Joe Venable, Deputy Director, says that individual units in the Young Marines spend a great deal of time investing the drug reduction program (personal conversation, March 25, 2011). It has proved to be beneficial. The Young Marines has received the Fulcrum Shield Award several times because of their dedication to spreading the anti-drug message. The Fulcrum Shield 
Award was created in honor of five military personnel who were killed while working on a drug case. Each year this award goes to a youth organization affiliated with the military that has shown exceptional efforts to spread the message of anti-drugs in their communities (www.umym.org/drugdemandreduction/id1.html). The Young Marines were the first recipients to receive the award in 2002.

The American Legion recently gave the National Young Marines organization a grant for $\$ 40,000$. The money will be used for the cloth materials needed for Red Ribbon Week. Red Ribbon Week takes place every year during the last week of October. Wearing the red ribbons and participating in community anti-drug events, young people pledge to live a drug-free life and pay tribute to DEA Special Agent Enriqué "Kiki" Camarena who was brutally murdered in 1985 by drug traffickers (www.justice.gov/dea/ongoing/redribbon_factsheet.html). The Young Marines is committed to promoting a healthy, drug-free lifestyle.

One parent shared in detail what she thought to be true of the Young Marines. Her perspective of the Young Marines is stated below:

The number one component of the Young Marines is living a drug-free life. It's learning discipline and leadership. They're structured like the military without the regime, hard-core military. The kids learn that there are boundaries, and that they have to respect those boundaries. They learn manners, hopefully, manners to their elders. They learn that community service is a huge factor in life, that you can't be self-centered. You've got to reach out in the community, and the kids thrive doing this. They love doing it but with the structure here. It's just 
overwhelming pride to see them perform in public at parades, etc, and the way they conduct themselves. If you compare them to just regular kids on the street, there is a gigantic difference. And hopefully those types of things they learn in this program will carry through life to make wise decisions, to make school your priority, stay free and away from drugs. Steer free of other people that are going to entice you to take these things and select your friends wisely and learn to be a group partnership not just an individual. There are consequences for your actions at all times (personal communication, November 18, 2010).

A number of parents reported that among the things being taught by the Quantico Young Marines, history and love of country were important. History comes alive in the Young Marines as they are given opportunities to interact with veterans, learning from the stories shared by veterans, and participation in special events that relate to history. One mother explained, "Youth get a lot of opportunity to see the value of what they're doing. Building bikes together at the warehouse for Toys for Tots really give a very tangible sense of the value that you are actually benefiting somebody (personal communication, December 06, 2010).” This same parent also shared how participating in an event at the Vietnam War Memorial Wall was an encouragement to Vietnam veterans as they observed how the Young Marines showed respect. "Making these kinds of connections seem worthwhile to kids as opposed to dropping a coin in a box at the Seven Eleven (personal communication, December 06, 2010).” 
Although history is not the primary focus of the Young Marines, parents were pleased with the special emphasis. Youth are taught the history of the United States' flag; understand US citizenship, the responsibilities of being an American, learning the National Anthem and the Pledge of Allegiance. Parents suggested this aspect of the program was unique because not all schools are able to devote sufficient time to teach all the aspects of citizenship. Some parents felt that when it comes to history, schools are not doing enough or are just covering the basics. While others felt schools were doing all that they could in this area. Parents stated that citizenship was important and youth need to have a better understanding of our history, and develop character qualities that are important in being a citizen. One parent said, "I feel that this program has reinforced the structure of what they do in school and obviously it has helped him” (personal communication, November 20, 2010).

One common thread throughout the interviews with parents was the effect the Quantico Young Marines had on the group as a whole. Several parents commented on how the social interaction among the group allowed everyone to fit in. You don't have to be a part of a sports team, and you don't have to have a particular skill. One parent summed it up:

Everyone is equal; you can't say that about school. In school there are different cliques. You have the jocks, you have the cheerleaders, you have the good people, and you have the bad people. Well, you know, here you got them all mixed in and they're all equal (personal communication, November 06, 2010). 
Every youth is given opportunity to receive more responsibility by working through their guidebook, earning ribbons, and being promoted regardless of age. There is no getting to the top by being popular or the best athlete. They become a leader by working hard and showing they can meet the challenge. Sometimes someone who is ten or eleven can be leading a group of Young Marines who are older than themselves.

\section{The Impact it Has Had on Their Youth}

Parents indicate that other Young Marines in this unit and the registered adult leaders have made a positive impact in their youth's life. Participation in the Quantico Young Marines has created a variety of developmental changes parents are seeing in their youth. Respect, leadership, self-confidence, public speaking, better attitude, demeanor, interaction with adults through leadership and mentoring, self-esteem, school improvement, discipline, making friends, and value of helping others are among the positive changes seen. One parent explained, "The character qualities we see spill over in his personality, and to other social activities, and especially in school” (personal communication, November 06, 2010). Another parent said, "He’s become an amazing public speaker because of the opportunities he's had with the Young Marines” (personal communication, September 18, 2010).

Several parents felt they already had great kids, but the Quantico Young Marines program further emphasizes the core values that were being taught at home. One grandfather explained, "There is a sense of accomplishment and pride that comes with succeeding” (personal communication, December 06, 2010). He went on to explain, 
during an armed forces dinner for wounded warriors, a three star general came up to a particular Young Marine and took notice of the chest full of ribbons he'd earned and said “that's an impressive array of accomplishments you have there in your awards". He went on to ask, "of those ribbons, which one do you take the most pride in"? The grandfather explained that the young man pointed to his presidential volunteer community service button and said, "this one, sir, for all the hours I've done in community service to help my community, our country, our veterans”.

Several single parents said the local program was achieving what they had hoped for, as some were seeking male mentoring for their child. Unfortunately some parents' circumstances don't allow for a male figure, but in this particular unit there are a number of adult registered leaders and older youth who are male. The program sparked an interest in one mother because she said "my son does not have an active male figure in his life. It falls back into that thing of the role model, you know, someone to look up to (personal communication, November 20, 2010)." Another parent said "there is no male figure in the household now, so this program kind of helps" (personal communication, November 09, 2010). Parents were pleased that their youth could be a part of a program where the adults were positive examples. Adult registered leaders are helpful because they address discipline issues when they arise, inquire about school, and encourage youth to work hard and earn good grades.

Social interactions between adult leaders and the youth were observed on many occasions during scheduled meetings and special events. The adult leaders were sincere and showed interest in talking to the youth on a personal level. Leaders talked with the 
youth about the Young Marines, encouraged them to sign up for SPACES (the Young Marines National Summer Program of: Adventure, Challenges, Encampments, and Schools) helped them fill out applications for programs, listened as they shared goals they were making for themselves, learned about activities the youth were doing outside the program in school and sports. Not only were adult leaders interacting with the youth, the youth were interacting with the adults. The youth appeared to be very comfortable and engaged in the conversation with the leaders, as well as other parents, Marines, and special guests. They were very respectful and courteous. In the event that there was a need to bring a Young Marine to the side to address an issue, two registered adult leaders would be present. This is a policy that all units abide by.

Parents expressed a variety of challenges their youth faced by participating in the Quantico Young Marines. One mother shared an experience when her son was challenged by the behavioral choices of other Young Marines, but made a choice to continue in a positive path of behavior. She stated, "Learning to work with diverse groups like this is important, where values and attitudes are not our own, because everyone lives in a diverse environment” (personal communication, December 06, 2010). Youth are challenged in a leadership role as they participate in numerous activities such as: bring order to the group, organizing drill, traveling out of state to participate in SPACES, giving short speeches, and interacting with adults in different social settings including guest speakers, Marines or other personnel.

The connection the adult leaders have made with the youth is obvious. The youth appear to be very comfortable coming to the leaders. Having this relationship is 
important as parents seek to put people in their youth's life that can make a positive impact. Parents pointed out that this organization can impact youth in a positive way, as they learn a great deal about history, gain skills in leadership, and are given many experiences not received outside a youth program. One parent explained, "It is important to keep in mind that the program helps you set goals and then it's up to you, the youth, to make that goal a reality. To make that goal a reality, you have to decide and make it a reality for yourself (personal communication, December 06, 2010).” These goals are met with support and nurturing from the registered leaders. She also shared that, "it is important to understand that whether it is in the Young Marines, school, or a job, the individual is responsible for their own prosperity or advancement”. Youth are taking advantage of these opportunities and seeking to make a difference.

\section{Why Parents and Youth are Giving Back to the Community}

The Young Marines' mission is “to nurture and develop its members into responsible citizens" (www.youngmarines.com). One way the Young Marines believe they can develop caring, responsible citizens is by encouraging the youth to participate in community service activities that benefit others. In order to receive a ribbon in community service, and/or be promoted in rank youth are committed to serving a minimum of 50 hours. "Being a good citizen means actively and purposefully participating in your community (www.youngmarines.com, Guidebook, pg. BYM-8-4).”

Youth are giving back to their community and parents are being supportive and often serve beside their youth in these endeavors. As one parent explains, "I think 
community service is very important for all Americans. I believe in order to receive, you need to give. You become connected to things and people in your country by participating in it. I think that that's a very good thing (personal communication, November 06, 2010).” While many parents support and participate along with their youth in community service, some parents do not. In conducting the interviews, some parents expressed that until joining the Quantico Young Marines they were not involved in community service beyond the typical food drive or helping a neighbor. Parents, however, were very supportive of the strong emphasis the program has and believe their youth are learning valuable tools.

Community service is an excellent way for youth to take the initiative and implement their own ideas on projects in the community. It was observed on one occasion that two different youth in the unit wanted to raise money for the Muscular Dystrophy Association (MDA), including one youth who has muscular dystrophy. Both youth organized their own website through the MDA and were able to recruit other Young Marines, along with family and friends, to participate in the MDA walk. On another occasion, it was observed seeing youth participate in a neighborhood cleanup. The activity was not broadcast to the whole unit, but through a few youth chatting decided to get together and clean things up.

The National Young Marines publish their own magazine called the Espirit. The magazine is distributed four times annually. Each time the magazine is submitted there is a new theme. The winter of 2011, volume one, was committed to the theme "United We Serve”. Young Marines provided a variety of exceptional ways youth are making an 
impact in other people's lives. They showed their passion for the communities in which they live by demonstrating it in a variety of ways. Some examples of ways youth are changing and strengthening their communities are: raising money for teachers to buy school supplies, leading a walk for the Out of the Darkness for the American Foundation for Suicide Prevention as well as educating kids at the event on the danger of drugs, alcohol, tobacco and gangs at the walk, attempting to show all veterans are loved and appreciated one youth in Georgia has made it her mission to send out cards to each and every one of them, having a food drive for a local food bank, having a car wash to raise money to send care packages to troops, pitched in to help clean up the bay after Hurricane Ike, and serving breakfast to local veterans.

Youth are encouraged to share how they are reaching out their communities by contacting the Young Marines Headquarters and sharing their ideas in the Espirit magazine or having it broadcast on the National Young Marines News Network. Along with sharing these great community service acts, youth are recognized for special achievements such as receiving the lifesaving award. There are great tips for internet safety and up close and personal truths about drugs and alcohol.

\section{Views on Youth Leading the Youth}

A strong emphasis is put on the youth leading the youth in this program. Adult registered leaders are visible and active with all youth during regular scheduled meetings and planned extra-curricular activities. The registered adult leaders put time and effort into teaching the youth how to take responsibility, lead their peers, and provide direction 
and structure when in charge. Youth are encouraged to help, support, and motivate one another at all times.

Several benefits were observed and mentioned when presented with the idea that the Quantico Young Marines appeared to be more of a youth-driven rather than an adultled program. Youth appeared to take ownership over activities, which require organization and leadership skills beneficial later in life. Youth were seen working as a team, planning, and communicating with one another, thereby demonstrating competence in their efforts and a strong motivation to succeed in certain tasks. Strength in public speaking is developed as they lead and help teach a variety of the classes. Public speaking takes place in a variety of ways, including school, public events, and in the unit classes. It was observed seeing an adult leader ask one youth to take charge in teaching a lesson from the guidebook that they all use and she did it with great ease. Youth showed support of one another as they worked together and earned ribbons in a wide range of areas. Although in most instances this behavior was not observed, on one occasion, while visiting the unit, it appeared that the youth in charge struggled to gain control of the unit and get them to listen to directions. In this particular insistent, it is unknown whether the struggle could have been alleviated by clearer instruction from other youth leaders, or the adult intervening to bring order. It is possible that this youth was not ready for this leadership role, but clearly this person was learning from the experience.

Parents had several positive things to say about youth leading the youth. One mother explained, “The adults are great, but the youth look up the older kids” (personal communication, November 13, 2010). Another parent said, “I think it’s wonderful 
because I think that they have a large input and they impact these younger children” (personal communication, November 20, 2010). She said that older kids have taken her child under their wing and have been an encouragement to him. She also stated, "Older youth had already had that life experience and they were at a different level in their life. My son has gained a lot from them, from boot camp, encampments, and other community service functions."

Regarding the youth-led aspect of the Young Marines, one parent said, "I think it gives them a sense of pride" (personal communication, December 06, 2010). Another went on to say it "makes it less intimidating” (personal communication, November 13, 2010). One mother shared a good example, "my young teen was not comfortable, but one youth in particular just listened to her, encouraged her, and helped her finish boot camp” (personal communication, November 20, 2010). She furthered explained that this young lady has continued to help her daughter by explaining the program in more detail and how to get the most out of her experiences. "I think it would be easy for an adult to stand up and lead the Young Marines and the other Young Marines follow suit,” said one father. He went on to say, “But it doesn’t teach the kids any leadership and it doesn’t teach them to deal with someone that's almost their peer that's in charge of them. It is something that you'll have to deal with for the rest of your life (personal communication, November 20, 2010).”

Parents have expressed that they feel comfortable in having their youth go to other youth and/or to the adult registered leaders. One mother stated, "I think they're well experienced adult leaders and also youth leaders and they have demonstrated 
genuine qualities to be in those positions. I think it is good leadership overall. They perceive and extend those good qualities, you know, using their examples for the younger ones (personal communication, November 13, 2010).” Parents feel fortunate to have great leaders, but understand that like any organization, leadership changes. Parents said that this program is special. Not every unit has leaders like this one. One mother hopes for more mentoring by adults to take place, thinking that more time spent working on the guidebooks together and more interaction would be helpful to her younger child who is in the program.

\section{Conclusion}

Several common threads emerged from the interviews that parents should consider when thinking about a program for their youth. Creating opportunities for youth to grow and develop skills are important. Youth are given a wide range of opportunity to broaden those skills as they interact with others and participate in structured activities organized by the youth leadership program. Parents want their kids to do well in school, be socially active, and participate in structured activities outside of school whether it be physical or recreational. They want to them interact with others, develop friendships and learn ways to give back to the community. The findings show or suggest that the services given by the Quantico Young Marines are making an impact in the lives of the youth involved. 


\section{Chapter Five}

\section{Discussion \& Implications}

This particular youth leadership program provides youth a wide range of opportunities. Among these opportunities are independent character building, achievement, leadership skills and the opportunity to give back to the community. Parents are an important part of the equation when making decisions about extracurriculum activities outside of school. Parents hope to see positive effects through participation. In-depth investigation of parents’ views and knowledge of the Quantico Young Marines help to further examine real-life dynamics of the program.

\section{Interpretations of the Results}

The interviews with parents, who have youth in the Quantico Young Marines, helped to gain a perspective of a youth leadership program that was not readily available before. The knowledge and experiences shared by parents gave considerable insight into the organization as a local unit and provided general information about the national organization. The findings from the interviews solidify data provided by the national organization. Parents expressed great support of the Quantico Young Marines and the adult leaders. This support helps those who do not have personal involvement in the program to see the personal effect the leaders bring to the group and the impact they are making as a unit. 
The data provided through the interviews make it clear that parents and youth choose the Quantico Young Marines over other local programs because of the emphasis they place on a drug-free lifestyle, character building, history, honoring veterans, structure, and military style atmosphere. While benefiting from the discipline that it offers to their youth, parents are excited that the program offers something that is fun for the youth. Parents emphasized that the skills that were being taught through the program are worthwhile. Parents like the unity of the group, offering that when the youth are in the Young Marines they are all part of the team.

Parents overwhelmingly said their youth were impacted by the program in a positive way, giving numerous examples. Parents shared ways in which the character of their youth has changed for the better. They are becoming better leaders, learning responsibility, and building more confidence. Parents like the fact that youth help lead the unit, giving them opportunities to develop their leaderships skills, along with public speaking and team work. Parents are seeing positive changes both at home and school in attitudes, grades and discipline. They also feel that the program is challenging, creating opportunities for personal growth.

Parents expressed the importance of serving in your local community. The Quantico Young Marines teach that volunteering is part of being a good citizen. Youth spend countless hours serving in their community, honoring veterans by participating in special events (ex. Memorial Day tributes and Flag Day ceremonies), along with participating in the annual Veterans Appreciation Week. Parents share that the youth really enjoy serving; therefore they do not mind sacrificing personal time to help out. It 
Parents' Perspective on the Young Marines

was clear, through stories and observation, that youth are willing to get their hands dirty to get the job done.

Character building and discipline, along with volunteerism were the primary reason for parents’ supporting; however, parents stated that history was also important. History is an integral part of the Young Marines guidebook giving youth a clear understanding of America’s past. Youth understand the importance of honoring veterans and are given ample opportunity to express admiration, appreciation, and respect for their service to our country.

\section{Potential Applications of the Findings}

Parents overwhelmingly supported the organization and shared numerous areas in which they are seeing success in the youth's personal lives. The findings show or suggest that the services given by the Young Marines, but particularly the local unit known as the Quantico Young Marines are making an impact in youths’ lives. Parents want to create an atmosphere where youth feel safe, are encouraged to develop leadership skills and other character building qualities, while making good decisions.

Parents take pride in seeing their youth succeed. The Quantico Young Marines creates an atmosphere where success is possible. Parents and the Young Marines can work side by side in developing the youth as they mature to become the future of America. Both, the parents and the Young Marines, help to educate the youth, cultivate their interests, and provide opportunities for success. The evidence shows that the adult registered leaders and other youth in the Young Marines are modeling good character 
qualities that help "strengthen the lives of America's youth" (www.youngmarines.com). Parents believe they are seeing positive effects of this program at home, in school, and in the community. While the parents were about to give a wide variety of positive ways the program was making a positive impact in their youth, I was unable to solidify this success through previous findings, research, or surveys on the life of Young Marines as they grow up and leave the unit entering the adult world. Data to back these findings were unable to be determined if they existed.

\section{Biblical Integration and Implications}

Engaging in activities that invest time and development in character qualities that improve a person's being is essential. Focusing on what we want to be is not nearly as rewarding as focusing on gifts that we can develop now to be effective for Christ today. Looking to God, our leaders, and those we have contact with can guide us in finding positive ways to increase God’s kingdom. Proverbs 11:14 (King James) states “Where no counsel is, the people fall: but in the multitude of counselors there is safety”. Without good direction, we will fall. Being in the company of wise counsel and following after those things that are right, we will be steered in a direction that is good.

We are made in the image of God with the intent to reflect God in all the things

we do. Love, joy, peace, longsuffering, kindness, goodness, faithfulness, gentleness, selfcontrol (Galatians 5:22-23) are examples of attributes that can help us reflect Christ in our own lives. Often we think of others as a means to better ourselves; however, we should use these characteristics for the benefit of others. We are obligated to serve, but 
often sin will interfere with our responsibilities to serve others. According to Dr. Eddie $\mathrm{K}$. Baumann in a three part article, The Essentials of Integration, as image-bearers of Christ, it is important that we understand what the goals of stewardship and reconciliation are, apply them in our own life, and then use them within the community.

One of our greatest obligations to Christ is to show love. Luke 10:27 states “...Thou shalt love the Lord thy God with all thy heart, and with all thy soul, and with all thy strength, and with all thy mind; and thy neighbor as thyself”. This verse is also referenced in Deuteronomy 6:5 and in Mark 12:30 where Jesus calls this the first and greatest commandment. "Properly loving God requires the dedication of our time, knowledge, resources, and abilities to the service of others so that they can also properly fulfill their obligation to be stewards of God (Baumann, 2007-2008, p. 34).”

We are also instructed to teach these things to our children. One of the greatest responsibilities of parents is to raise up children into Godly men and women. Good parenting requires intentional, continuous instruction according to Daniel A Thompson, in Training the Next Generation. We are commanded as parents to pass on our knowledge of God, creating opportunities of intentional instruction in the word of God for our children. Deuteronomy 6:7 states "And thou shalt teach them diligently unto thy children, and shalt talk of them when thou sittest in thine house, and when thou walkest by the way, and when thou liest down, and when thou risest up”. Knowing God and living our lives for God is a lifelong process that is often cultivated through intentional learning. Ultimately, the most effective way of teaching our youth is by our example. 
According to Psalm 145:3-4, "One generation shall praise thy works to another, and shall declare thy mighty acts. I will speak of the glorious honour of thy majesty, and of thy wondrous work." So, who will train the next generation? "I must be their example, and it is my God-given privilege to teach my boys how to become men who will "praise His works" to the next generation (Answers, Jan-Mar. 2011, Training the Next Generation, pg. 79)." What is taught in the Young Marines has to be supported at home.

The Young Marines face the same ideal that believers face when we walk out of the church. When the uniform comes off, the Young Marine has to be equipped to do what is right when no one is looking. The integrity of the Young Marine is the same as a believer when he is alone. I am reminded of the Titanic, the great luxury liner that sank in the Atlantic Ocean in 1912 because it collided with an iceberg. They were deceived by what they saw on the surface. It was not what was seen on $10 \%$ of the surface, but the 90\% below the surface that made all the difference.

\section{Relation of the Results to Theory and Other Literature}

Research shows that as youth transition into adulthood, they need more assistance indicating that youth leadership organizations are important. Teens struggle for a variety of reasons. In an environment where both parents are working, there is more single parent homes, lack of program availability, and volunteer help within the organization a good program is more difficult to find. While there are great programs available to our youth, "one program, even an extraordinary good program, cannot do it all. Young 
people do not grow up in programs, but in families, schools, and neighborhoods (Roth \& Brooks-Gunn, 97).”

Research reinforces the need for character qualities as they reach adulthood. Success is seen in research where youth leadership programs are providing a structured environment focused on character building. Although the literature supports character building, it also supports the need for opportunity. Youth in the Young Marines work on character building, while enhancing personal skills by serving in their community. A variety of opportunity is available for youth who wish to volunteer in the community and work closely with veterans.

\section{Strengths of the Study}

Focus on one particular unit within the national organization of the Young Marines allowed for strength within the research. This allowed for a more intimate experience as observations were cited and contact with parents was made. Having the visual contact allowed parents and adult workers to interact with the researcher during meetings/activities on a more personal level.

\section{Limitations of the Study}

There were limitations of the study even though conducting an in-depth study on the local Young Marines unit in Quantico, VA was manageable for one person. This study involved interviewing a number of different individuals and it would have been helpful to have another interpreter available to conduct interviews. No private funding 
was provided making the extent of the research limited. Having proper funding would have made it possible to further solidify the findings through surveys after the interview process.

An additional limitation is the sample size, making the study less comprehensive. The Quantico Young Marines has 54 registered families. Only 18 parents signed consent forms and participated in the interview process. This may have been a problem for some because parents do not stay for meetings and a few parents were active members of the military and had been deployed during the interviewing process. Another possible cause may have been because some parents were not consistent in having their Young Marine attend, and a few were unwilling to participate in the interview process.

\section{Suggestions for Future Research}

Further examination of the dynamics of the Young Marines is needed. This study raises further questions and inquiry for other in-depth studies. There is a need to critically evaluate other units within the national Young Marine organization. This study was limited only to one unit and it would be beneficial to know whether parents feel the same nationwide or if the perspectives shared are central to this unit only. It is essential to study the effectiveness of the program nationwide as a leadership program for a better analysis. Resources available at this time may limit a study; however, conducting a study with support of a larger research team may add more insight. A case study could be used to strengthen results and explore different aspects of the Young Marines outcomes (immediate, short-term, and long-term). Further evaluation of the relationship between 
the leaders and the youth could be studied, along with gathering data on the socioeconomic groups being serviced. Developing a study that compares the Young Marines to other youth programs and their involvement in giving back to their community could also prove to be beneficial.

\section{Conclusion}

There are many ways in which our youth can be influenced by society as it addresses the need to develop character, values, attitudes and service to the community. Parents struggle to compete with peers, media and other sources as youth seek for acceptance. Previous research supports the need for quality youth programs. It also supports the idea that there is a wide variety of information on youth programs available.

The possibilities are endless, and the research on some is quite thorough as perspective is gained from parents, youth and leaders in different organization. According to the Young Marines National Headquarters, The Young Marines program is an important youth leadership program that offers a safe environment where youth are encouraged to live a drug-free life that promotes the mental, moral, and physical development of its members. Parents, along with school and the Federal government, have taken great lengths to see that young people are provided opportunities to develop character and leadership skills.

As parents explore all their options, this study will give insight into the Young Marines program as a whole, but particularly as a local organization. The Young Marines offer a program that is unique because it focuses on being drug-free. This study 
is important because although the Young Marines is nationwide, they are not well known. Knowledge about this program will help build awareness, giving parents an alternative they may not have known existed. Jensen notes in his article, Ivory Towers or Earthen Trenches? Community Collaborations to foster "real world" Research, that youth and families should be active participants in shaping and evaluating programs, not just researchers.

Ultimately as believers we have also been instructed to train our children (Proverbs 22:6). While using youth organizations, schools, religious organizations, and family as a way to equip our youth is good, it is primarily the responsibility of the parent. As parents it is our responsibility to establish a foundation that our children can rely on which is grounded in God's Word. We have been created in God's image (Gen. 1:27). As youth transition into adulthood, serving others is a great way to help build a healthy character. When we reach out to others through service, we reflect Christ. Christ is our greatest example of serving. Micah 6:8 states, "He has showed you, O man, what is good. And what does the Lord require of you? To act justly and love mercy and walk humbly with your God.” 


\section{References}

Amodoe, M., Collins, M. E. (2007). Using a positive youth development approach in addressing problem-oriented youth behavior. Families in Society: The Journal of Contemporary Social Services, 88(1), 75-85. doi: 10.1606/1044-3894.3594

Anderson-Butcher, D., \& Cash, S. J. (2010). Participation in boys \& girls clubs, vulnerability, and problem behaviors. Children and Youth Services Review, 32, 672-678.

Baumann, E. K. (2007-2008). The essentials of integration: The principle of stewardship. Christian School Education, 13(4), 32-34.

Bush, L. (2005). Helping America’s youth. Reclaiming Children \& Youth, 14, 69-70.

Garst, B. A., \& Bruce, F. A. (2003). Indentifying 4-H camping outcomes using a standardized evaluation process across multiple 4-H educational centers. Journal of Extension (on-line), 41(3), article 3RIB2. http://www.joe.org/joe/2003june/rb2/php

Hedrick, J., Homan, G., \& Dick, J. (2009, December). Exploring the positive impact of 4H camp on youth: Identifying differences based on a camper's gender, years of attendance, and age. Journal of Extension (on-line), 47(6). Retrieved from http://www.joe.org/joe/2009december/pdf/JOE/_47_6a5.pdf 
Parents' Perspective on the Young Marines

Jensen, P., Hoagwood, K., Tricketet, E. (1999). Ivory towers or earthen trenches? Community collaborations to foster "real world" research. Applied Developmental Science, 3(4), 206-212.

Lerner, R. M., Fisher, C. B., \& Weinberg, R., A. (2000, Jan/Feb). Toward a science for and of the people: Promoting the civil society through the application of developmental science. Child Development, 71(1), 11-20.

Pritchard, I. A. (2001). Raising standards in community service learning. About Campus, 6, 18.

Raskoff, S. A., \& Sundeen, R. A. (1999, Autumn). Community service programs in high schools. Law \& Contemporary Problems, 62, 74-117.

Rhodes, J. E., Bogat, G. A., Roffman, J., Edelman, P., \& Galasso, L. (2002). Youth mentoring in perspective: Introduction to the special issue. American Journal of Community Psychology, 30, 149.

Roth, J. L., \& Brooks-Gunn, J. (2003). What exactly is a youth development program? Answers from research and practice. Applied Development Science, 7(2), 94-111.

Sullivan, P. J., \& Larson, R. W. (2010). Connecting youth to high resource-adults: Lessons from effective youth programs. Journal of Adolescent Research, 25(1), 99-123. 
Parents' Perspective on the Young Marines

Thomas, D. A. (Jan-Mar, 2011). Training the next generation. Answers Magazine, 6(1), 79.

Urban, J. B. (2008). Components and characteristics of youth development programs: The voices of youth-serving policymakers, practitioners, researchers, and adolescents. Applied Developmental Science, 12(3), 128-139. doi:

$10.1080 / 10888690802199400$

A year in the life of a cub scout...boy scout...venture. (n.d.). Retrieved from http:///www.scouting.org/About/Research/YearintheLife.aspx

Boys and Girls Club of America (2010). Retrieved from http:www.bgca.org

Boy Scouts of America (2010). Why scouting? Retrieved from http://www.scouting.org/visitor/whyscouting.aspx

Corporation for National \& Community Service (2010). Government support for volunteering. Retrieved from http://www.nationalservice.gov/about/volunteering/government.asp

Grimm, R., Dietz, N., Spring, K., Arey, K., \& Foster-Bey, J. (2005, November). Building active citizens: The role of social institutions in teen volunteering. Corporation for National \& Community Service. Retrieved from http://nationalservice.gov/about/role impact/performance/research.asp\#YHA 
Parents' Perspective on the Young Marines

Kessler, M. (Producer). (2010). Young marines - Our history: Strengthening the lives of America's youth [DVD]. USA: Dynamix Productions.

National Clearinghouse on Families \& Youth. (2010). Putting positive youth development into practice: A resource guide. Retrieved from http://ncfy.hhs.gov/

Search Institute (2010). What kids need: Developmental assets. Retrieved from http://www.search-institute.org/developmental-assets/

The I believe Bible: The complete solution for all your Bible learning needs [computer software]. (2001). Legends of the Faith, Inc.

www.cylc.org/NYLSC

www.justice.gov/dea/ongoing/redribbon_factsheet.html

www.umym.org/drugdemandreduction/id1.html

www.youngmarines.com 


\section{APPENDIX A}

Interview Consent letter

Consent for participation in research project: Parents’ Perspective on the Young Marines as a Youth Leadership Program

Dear Parent or Guardian,

You have been invited to participate in a research study investigating parents' views on the Young Marines. You have been selected based on the fact that you have a son or daughter in the Young Marine’s in Quantico, VA.

I am Rebecca Van Deusen, a graduate student at Cedarville University, completing my Master's of Education. There will be no direct benefit to you for participating in this project. However, when the study is complete, it will benefit others who research youth leadership programs. There are no foreseeable risks or discomforts associated with this study, other than the inconvenience of time. You will not be subjected to sensitive questioning and there is no cost to you. I will not hide anything from you about the interview and you may decline to answer any question during the interview.

Participation in this study is completely voluntary. A decision not to participate will involve no penalty or prejudice on the part of Cedarville University or the Young Marines. You are free to discontinue participation in this interview, and should you decide to withdraw from participation any data collected up to that point will be destroyed.

During the interview you will be asked open-ended questions about the Young Marines and your personal reasons for choosing the program. The interview will take approximately 30 minutes. I will keep all information shared during the interview confidential. Safeguards will be used to assure your anonymity and confidentiality. No names will be associated with the taped recordings and typed transcripts. Results will be kept under locked file and the results of which will only be disclosed as an aggregate. Results of the study will be made available to Cedarville University and other associations or publications interested in youth programs.

If for any reason you have specific questions regarding this interview, please contact:

Rebecca Van Deusen

55 Dorothy Lane

Stafford, VA 22554

540-720-1704 
If you have complaints about the interview, please contact:

Dr. Eddie Baumann

Cedarville University

P.O. Box 601

Cedarville, OH 45314

937-766-7780

Although Dr. Baumann will ask your name, all complaints are kept in confidence.

I hereby grant Rebecca S. Van Deusen permission to document through audio recording, for the purpose of gaining knowledge and insight why families choose this unique youth leadership program called the Young Marines and the benefits they see from this program. The information I agree to share with the interviewer is to be used solely for the purposes of the research. I understand that a transcription company has been hired to type this interview. They also have signed a privacy consent form. When this material becomes available, it may be read, quoted, or cited from and disseminated for educational and scholarly purposes only.

Signature of Interviewee

Print Name
Signature of Interviewer

Print Name

Date

This research project has been approved by Cedarville University Institutional Review Board for the protection of human subjects for a one year period. 


\section{APPENDIX B}

\section{Thesis Questions}

\section{Pilot Study}

1) What are some of the things your child did to become a Young Marine?

2) Tell me some of the things your child is doing in the program.

3) Does your child like doing community service?

4) Why did your child join the YM's?

5) What character qualities do you see in your child changing, if any?

6) What long-term intentions do you have for your child (future Marine, discipline)

7) Are you having discipline issues at home and hope to see an improvement by having them involved in a program like this?

8) At what cost must they succeed (peer pressure, failure, giving up, work overload)?

9) With the waiting list to get into boot camp being one year, why do you wait?

10) Do you think of the leaders as mentors? 


\section{APPENDIX C}

Thesis questions

1. How long have you been in the program? (child's name, age)

2. Who decided to join the YM? You or him?

3. With the waiting list to get into boot camp being one year, why do you wait? What is it that you like (heard) about the YM that would make you stay?

4. Tell me about the program?

5. What are some of the things your child did to become a YM?

6. What kind of work does it entail to be a YM?

7. Do you feel you need a youth program? Have you tried other programs?

8. Why do you join?

9. Is there competition to earn rank, and at what cost must they succeed?

10. Is quitting an option for your child? If they want to stop coming would you encourage them to stay?

11. Tell me about the registered adult leaders?

12. What do the registered leaders do to encourage the kids to read and memorize the book?

13. Do you like having the youth lead the unit? What things do you see from the other youth in YM?

14. The Young Marine's has put a strong emphasis on community service, do you want him/her to serve?

15. Did you do community service when you were growing up? 
16. Was your child serving before he got started in the YM?

17. Do the kids mind doing community service?

18. With so many opportunities for service, how do you find a balance between community service and family time?

19. Do you see any qualities developing in your child b/c of participation in the YM? Can you give me some examples?

20. Why do you stay in the program?

21. Has your child been challenged in the YM's? Can you give me an example of when your child has been taking out of his comfort zone and really grown? 
APPENDIX D

Young Marines Photos

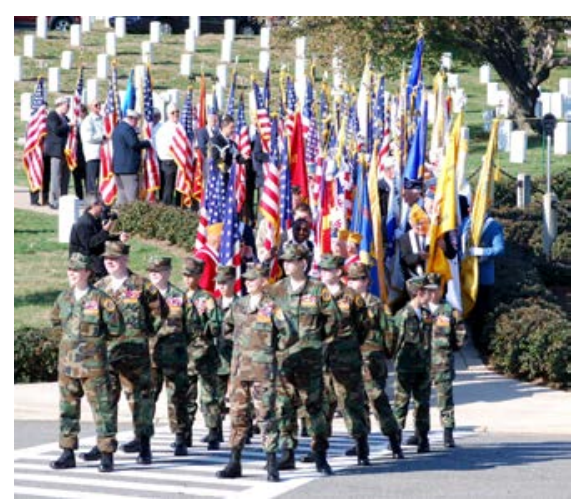

Gathering of Flags - Veteran's Day

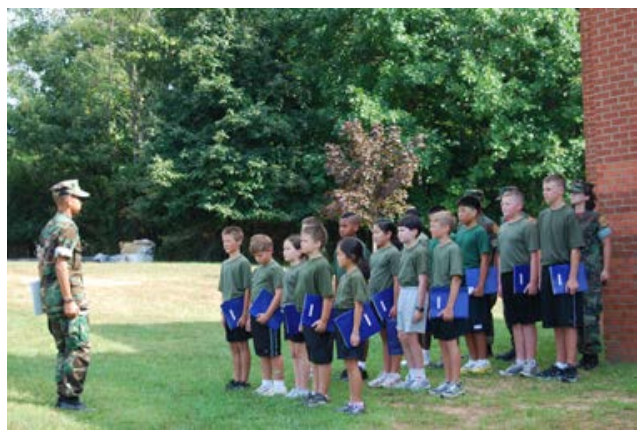

\section{Boot Camp}

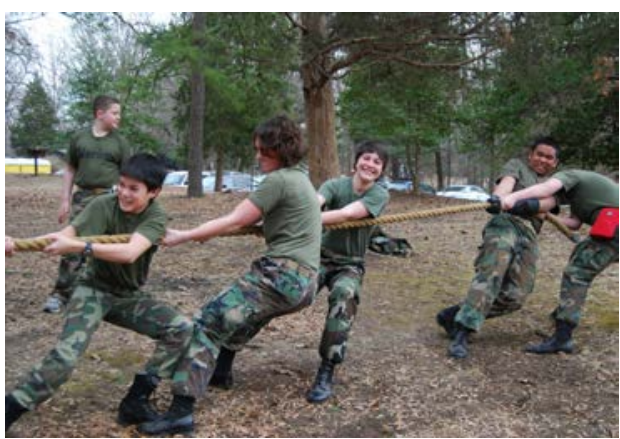

Weekend Encampment
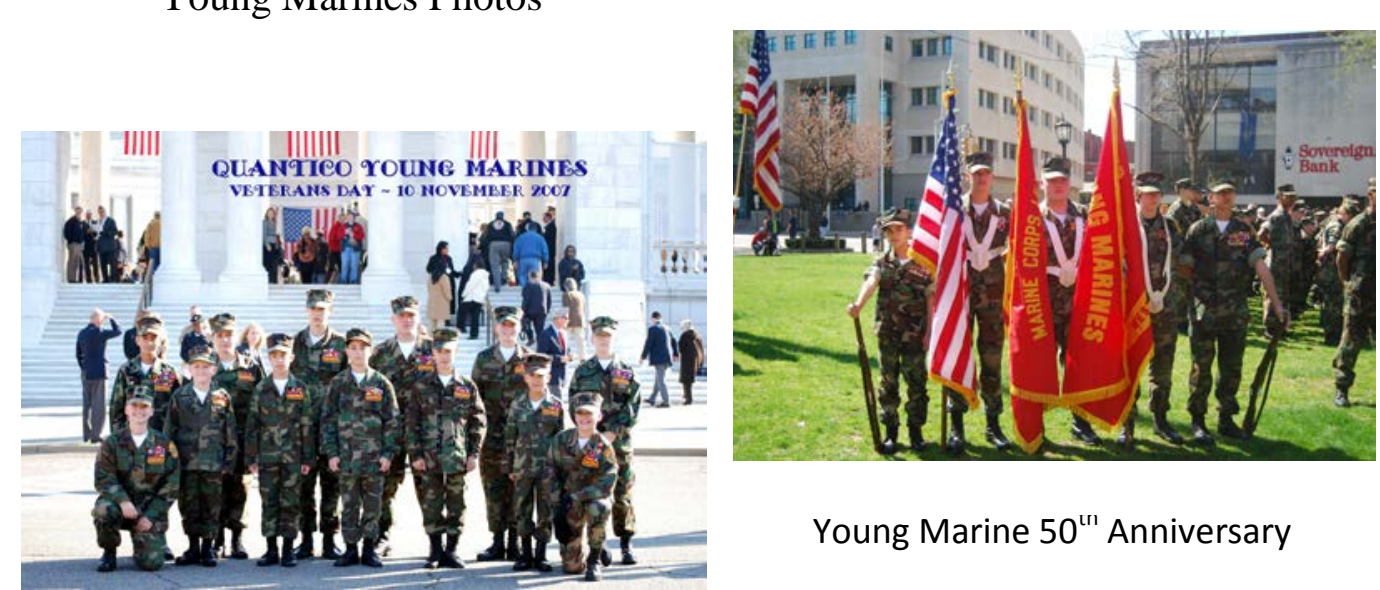

Young Marine $50^{\text {"n }}$ Anniversary

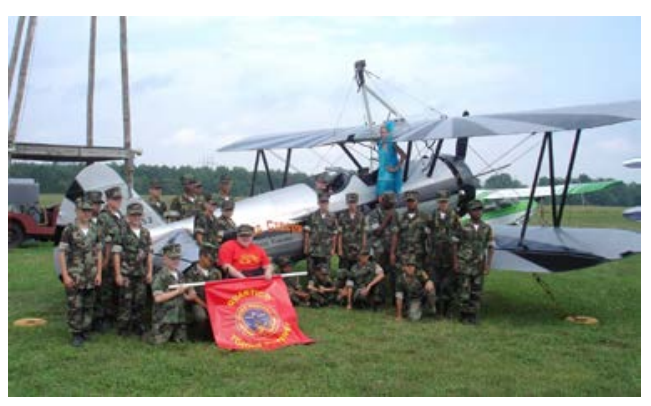

Flying Circus

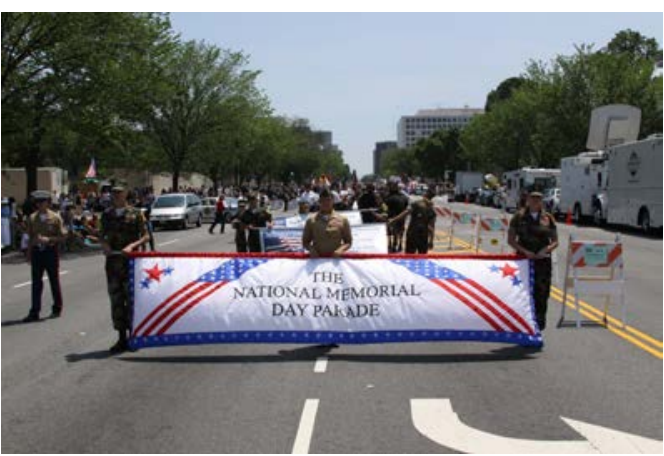

Memorial Day
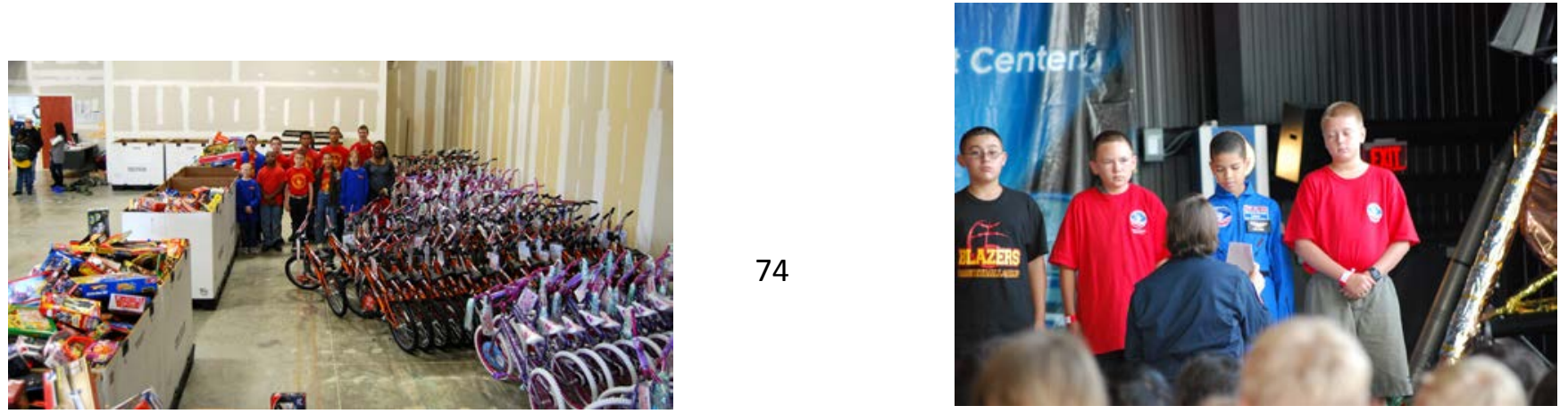